\title{
Implementasi Konsep Islam Ramah Lingkungan
}

\author{
Rahma Hazalia', Indah Muliati² \\ rahmahazalia@gmail.com¹, indahmuliati1979@gmail.com² \\ Universitas Negeri Padang1,2
}

\begin{tabular}{|c|c|}
\hline ART & \multirow{13}{*}{$\begin{array}{l}\text { This study aims to examine the implementation of the } \\
\text { concept of environmentally friendly Islam at MTsN } 2 \text { Padang } \\
\text { Pariaman. This study uses a qualitative method with a } \\
\text { descriptive approach. The data used in this study were taken } \\
\text { through direct interviews with seven madrasah residents } \\
\text { consisting of the principal, administrative staff, two teachers, } \\
\text { and three students. This study was conducted to describe (1) } \\
\text { the concept of environmentally friendly Islam in schools. (2) } \\
\text { Implementation of environmentally friendly Islamic concepts } \\
\text { in schools. (3) Inhibiting and supporting factors in the } \\
\text { implementation of environmentally friendly Islamic concepts } \\
\text { in schools. After the data was obtained and then analyzed, it } \\
\text { was found that the concept of environmentally friendly Islam } \\
\text { at MTsN } 2 \text { Padang Pariaman there were four concepts } \\
\text { applied, namely maintaining cleanliness, reforestation, } \\
\text { preserving natural resources, and maintaining human health. } \\
\text { The implementation of the environmentally friendly Islamic } \\
\text { concept in this school has begun to be implemented well. Such } \\
\text { as being prohibited from littering, making compost, planting } \\
\text { ornamental or medicinal plants, and having routine controls } \\
\text { from the Puskesmas to students. }\end{array}$} \\
\hline Artic & \\
\hline Received, 07 Februari & \\
\hline & \\
\hline Revised, 17 Februa & \\
\hline $\begin{array}{l}\text { Accep } \\
2022\end{array}$ & \\
\hline Keywords: & \\
\hline asi, Kon & \\
\hline Islam, Ram & \\
\hline Clonflic & \\
\hline None & \\
\hline Fun & \\
\hline None & \\
\hline
\end{tabular}

Corresponding Author: Rahma Hazalia, Department Islamic Education Faculty of Social Science Universitas Negeri Padang, Indonesia, Email rahmahazalia@gmail.com, Phone No.: $+6282114468650$

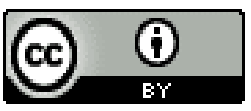

Copyright@2022, Author(s)

\section{Pendahuluan}

Islam adalah agama yang sempurna dan rahmat bagi semesta alam. Islam merupakan agama yang luas, mendalam dan terpadu. Islam tidak hanya berbicara fiqh (hukum), tapi juga sains, teknologi, sejarah, ekonomi, politik, pendidikan dan aspekaspek lainnya (Muhammad Alim, 2011; Engkizar et al., 2018). Dalam Islam, manusia menjadi pusat sasaran ajarannya, baik hubungan manusia dengan Tuhan, hubungan dengan sesama manusia ataupun hubungan manusia dengan alam (Engkizar et al., 2021; Kaputra et al., 2021). Hubungan manusia dengan alam mencakup beberapa aspek, yakni hewan, tumbuhan, lingkungan dan lainnya.

Islam mendorong manusia untuk mengolah dan menjaga potensi alam dengan baik. Melalui kitab suci al-Qur'an membuktikan bahwa Islam adalah agama yang 
Rahma Hazalia dan Indah Muliati: Implementasi Konsep Islam Ramah...

mengajarkan kepada umatnya untuk bersikap ramah terhadap lingkungan. Sebagaimana yang disebutkan dalam firman Allah SWT dalam QS. Al-A'raf ayat 56:

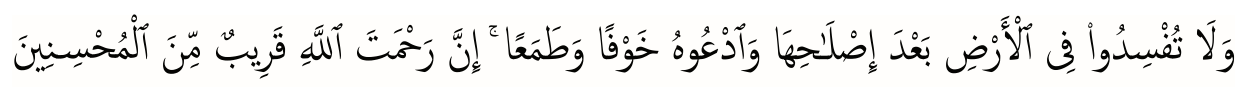

Terjemah:

"Dan janganlah kamu berbuat kerusakan di bumi, setelah diciptakan dengan baik. Berdo'alah kepada-Nya dengan rasa takut dan penuh harap. Sesungguhnya rahmat Allah sangat dekat kepada orang yang berbuat kebaikan".

Banyak contoh yang dapat kita lihat dari kerusakan lingkungan yang diakibatkan ulah manusia. Contohnya saja banyak pohon atau hutan yang ditebang dan dibakar tanpa usaha untuk menanamnya kembali, bukit-bukit digali untuk mengurug daratan rendah untuk dijadikan pemukiman, membuang sampah sembarangan, dan lain-lain. Akibatnya banyak musibah yang terjadi seperti banjir, tanah longsor dan sebagainya terjadi dimana-mana. Kemudian binatang yang hidup di sungai dan di laut ditangkap dengan cara yang tidak baik, seperti diracun dan lain-lain. Akibatnya terumbu karang pun rusak dan punahnya ekosistem laut.

Melihat banyaknya masalah lingkungan yang terjadi saat ini, maka kita sebagai penduduk penghuni bumi berperan besar dalam menentukan kelestarian lingkungan. Konsep Islam sebagai agama yang ramah terhadap lingkungan beranjak dari fungsi manusia sebagai khalifah di muka bumi, fungsi tersebut menuntut adanya interaksi harmonis antara manusia dengan sesamanya, dan manusia dengan alam sesuai dengan petunjuk-petunjuk Ilahi yang tertera dalam wahyu-Nya (Indah Muliati, 2019). Yang mana interaksi harmonis tersebut dapat berupa kewajiban manusia untuk menjaga terhadap lingkungan yang dilakukan dengan banyak cara.

Di antara konsep yang dianjurkan Islam dalam memelihara lingkungan adalah dengan memperhatikan masalah kebersihan. Dan pada hakikatnya pandangan Islam terhadap kebersihan merupakan sebuah prinsip yang tidak disangkal dalam agamaagama lain, karena kebersihan adalah ibadah bahkan merupakan tindakan yang diwajibkan. Dalam Hadits Riwayat Muslim dari Abu Malik al-Asy'ari dalam Bab Thaharah dikatakan bahwa:

Terjemah:

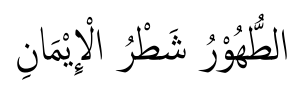

"Kebersihan (kesucian) itu bagian dari Iman".

Penerapan konsep ramah lingkungan ini sangat mempengaruhi bagaimana keadaan bumi kita mendatang. Untuk itu penerapan konsep Islam ramah lingkungan harus ditanamkan sejak usia dini, yang mana dapat ditanamkan melalui keluarga maupun sekolah. Sekolah menjadi institusi yang sangat berperan penting dalam dunia pendidikan, yang diharapkan dapat membantu menanamkan karakter sejak dini pada peserta didik (M. Wildan, 2018). Melalui sekolah diharapkan siswa memperoleh pengatahuan tentang pelestarian lingkungan yang kemudian dapat diterapkan dalam kehidupan sehari-hari. Konsep Islam ramah lingkungan di sekolah dapat diterapkan melalui beberapa kegiatan lingkungan yang melibatkan warga sekolah. Seperti kegiatan penghijauan, melakukan pemilahan sampah, pemanfaatan dalam penggunaan lahan serta pembiasaan sehari-hari seperti menjaga kebersihan dan kegiatan lainnya. 
Dengan adanya konsep Islam ramah lingkungan ini akan menciptakan warga sekolah, khususnya peserta didik yang peduli dan berbudaya lingkungan.

Salah satu sekolah yang menerapkan konsep Islam ramah lingkungan adalah MTsN 2 Padang Pariaman. Hal ini terlihat dari lingkungan sekolah yang bersih dan asri. Dan juga sekolah ini merupakan satu-satunya MTs di Kabupaten Padang yang mendapatkan penghargaan sebagai sekolah adiwiyata tingkat provinsi. Sebagaimana yang kita ketahui bahwa sekolah adiwiyata adalah sekolah yang ramah lingkungan yang bertujuan untuk menciptakan warga sekolah yang mempunyai kepedulian dan berbudayaan lingkungan. Dari data yang peneliti dapatkan dari observasi awal, bahwa penerapan konsep Islam ramah lingkungan yang dilakukan oleh sekolah ini adalah dengan kegiatan-kegiatan sekolah berupa kegiatan lingkungan seperti menanamkan kebiasaan-kebiasaan baik yakni tidak membuang sampah sembarangan, memilah sampah dengan benar, adanya rumah kompos, dilarang merokok di lingkungan sekolah serta daur ulang sampah, yang mana itu semua merupakan bentuk konsep Islam ramah lingkungan dalam hal menjaga kebersihan. Selain itu bentuk penerapan lainnya dengan adanya green house, membuat serapan air atau lobang biopori, menanam pohon pelindung, penanaman tanaman yang bisa menyerap genangan air serta adanya program 9K yang menjadikan siswa dapat mengembangkan pengetahuan dan kreativitasnya.

Terkait isu dan permasalahan yang penulis angkat dalam penelitian ini, perlu dijelaskan bahwa penelitian terkait dengan konsep islam ramah lingkungan telah banyak dilakukan oleh peneliti sebelumnya. Namun, pada penelitian sebelumnya lebih terfokus kepada bentuk pelestarian lingkungan dalam pandangan islam, yang mana tujuannya adalah mengetahui hakikat pelestarian lingkungan dalam pandangan islam (Hipzon, 2018), konsep islam tentang lingkungan hidup secara sains dan tujuannya yaitu untuk mengetahui konsep islam tentang lingkungan hidup secara sains dan peran islam dalam pemeliharaan lingkungan (Saharuddin, 2014), dan praktik pertambangan menurut Yusuf al-Qaradhawi, yang tujuannya yaitu untuk menjelaskan perspektif yusuknal-qaradhawi tentang praktik pertambangan (Eva nur afifah, 2019). Terkait bagaimana konsep Islam ramah lingkungan di sekolah belum ada dibincangkan. Justru itu penulis menilai penelitian yang bertujuan untuk mendeskripsikan bagaimana implementasi atau penerapan dari konsep islam ramah lingkungan di MtSN 2 Padang Pariaman ini perlu diangkat mnjadi sebuah kajian ilmiah dalam kerangka memperkaya literatur dan mengeksplorasi tentang konsep islam yang ramah lingkungan di sekolah.

\section{Tinjauan Pustaka}

Islam memerintahkan penganutnya untuk mempraktekkan hidup bersih dan sehat. Dalam ajaran Islam, terdapat sumber-sumber dan kajian yang menjelaskan cara manusia menjaga hidupnya, keluarganya dan lingkunganya. Dalam hal ini, alqur'an dan sunnah serta ilmu fikih telah menjelaskan bagaimana sepatutnya interkasi manusia dengan lingkungannya.

Ilmu fikih adalah ilmu yang mengatur hubungan manusia dengan Tuhannya, dengan dirinya, dengan keluarga dan masyarakatnya, dan dengan alam sekitarnya sesuai dengan lima hukum-hukum syariat yang sudah dikenal luas yaitu wajib, sunnah, haram, makruh dan mubah (Yusuf al-Qardhawi, 2002; Murniyetti et al., 2022).

Hubungan fikih dengan lingkungan tidak hanya terbatas pada wilayah hukumhukumnya semata, tapi juga berhubungan erat dengan kapasitasnya sebagai dasar 
Rahma Hazalia dan Indah Muliati: Implementasi Konsep Islam Ramah...

pembentukan hukum secara universal. Yang mana telah melahirkan bahasan-bahasan dalam literatur yang amat banyak, yang dalam bahasan-bahasan itu menyinggung pentingnya memberikan perhatian terhadap lingkungan, serta bagaimana Islam mengatur dan memeliharanya. Karena di dalamnya memang dipaparkan prinsipprinsip pemeliharaan lingkungan dengan amat terpuji (Yusuf al-Qaradhawi, 2002).

Jadi dapat dipahami bahwa pemeliharaan lingkungan dalam perspektif ilmu fikih adalah pembahasan-pembahasan mengenai pentingnya perhatian terhadap lingkungan sangat banyak dibahas dalam ilmu fikih, salah satunya adalah pembahasan mengenai menghidupkan lahan yang mati dalam fikih muamalah. Tidak hanya itu, fikih juga membahas tentang cara pelestarian lingkungan, solusi serta fikih juga mengatur sanksi apa yang harus diberikan kepada manusia yang merusak alam.

Dalam al-Qur'an surah al-Ahzab ayat 36 dikatakan bahwa: "Dan tidakkah patut bagi laki-laki mukmin dan tidak (pula) bagi perempuan mukminah, apabila Allah dan RasulNya telah menetapkan sesuatu ketetapan, akan ada bagi mereka pilihan (yang lain) tentang urusan mereka. Dan barang siapa yang mendurhakai Allah dan Rasul-Nya, maka sungguh dia telah sesat, sesat yang nyata."

Ayat di atas megaskan kewajiban kaum muslimin untuk menaati al-Qur'an dan sunnah. Mengenai dalil-dalil yang memberi perhatian terhadap lingkungan adalah nama-nama surat beserta muatan dalil yang dikandungnya. Dalil-dalil al-Qur'an yang memberikan perhatian yang sangat besar pada lingkungan adalah berupa nama-nama surat yang memakai nama-nama hewan, serangga, tumbuh-tumbuhan, nama-nama tambang, serta nama-nama alam lainnya (Yusuf al-Qardhawi, 2002). Contoh yang amat jelas adalah surat al-Baqarah, surah al-An'am, surat al-Fiil dan surat al-Adiyat yang semua nama-nama surat ini diambil dari nama-nama hewan. Begitu juga dengan surat an-Nahl, surat an-Naml, surat al-Ankabut yang semuanya adalah nama-nama serangga. Selain itu kita juga menemukan surat ath-Thur yang berarti gunung secara umum ataupun gunung tertentu, surat al-Balad yang maksudnya adalah Makkah (tanah haram), surat al-Ahqaf yaitu kawasan Arabia, surat al-Hajr dan surat al-Kahfi yang semua surat ini dari nama-nama tempat.

Dari nama-nama yang tersebut dalam al-Qur'an tadi, mempunyai implikasi penumbuhan kesadaran dalam diri manusia supaya terikat dengan lingkungan dan alam sekitarnya, sehingga manusia tidak melalaikannya dan akan terus melestarikannya.

Selain dasar-dasar normatif diatas, Islam juga memperkenalkan konsep islam ramah lingkungan. Konsep ini memiliki banyak manifestasi seperti dalam penanaman pohon, pemanfaatan lahan mati, menjaga kebersihan dan sumber daya alam, menjaga Kesehatan manusia, berperilaku adil kepada semua makhluk ciptaan-Nya, dan tidak berlebhihan dalam melakukan sesuatu, termasuk ketika memanfaatkan lingkungan.

Lingkungan berasal dari kata lingkung yaitu sekeliling, sekitar. Lingkungan adalah kawasan wilayah dan segala sesuatu yang terdapat di dalamnya (Bambang Marhijanto: 228). Lingkungan merupakan segala benda, kondisi atau keadaan dan pengaruh yang terdapat dalam ruang yang kita tempati dan mempengaruhi hal-hal yang hidup termasuk kehidupan manusia (M. Tholhan Hasan, 2004: 315).

Lingkungan menurut Islam mencakup semua usaha kegiatan manusia dalam sudut ruang dan waktu. Lingkungan ruang, mencakup bumi, air, hewan dan tumbuh- 
tumbuhan serta semua yang ada di atas dan di dalam perut bumi, yang semuanya diciptakan Allah untuk kepentingan umat manusia untuk menunjang kelangsungan hidupnya (Chakalica Widyadipraja, 2020). Dari pendapat di atas, maka dapat disimpulkan bahwa lingkungan adalah segala sesuatu yang ada di sekitar manusia yang mempengaruhi perkembangan hidup manusia baik secara langsung maupun tidak langsung serta dipandang sebagai tempat beradanya manusia dalam melakukan segala aktivitas sehari-hari.

Menurut Indah Muliati (2019), pentingnya pemeliharaan lingkungan berpijak pada lima konsep mashlahat, yaitu pertama, menjaga lingkungan sama dengan menjaga agama. Segala daya upaya yang berkaitan dengan pemeliharaan lingkungan adalah sama halnya dengan usaha menjaga agama. Kedua, menjaga lingkungan sama dengan menjaga jiwa. Menjaga lingkungan dan melestarikannya sama dengan menjaga jiwa, yakni perlindungan terhadap jiwa adalah perlindungan terhadap kehidupan psikis manusia dan keselamatan mereka. Ketiga, menjaga lingkungan sama dengan menjaga keturunan. Menjaga lingkungan sama dengan menjaga keturunan, yakni keturunan manusia di bumi ini. Maka menjaga keturunan mempunyai arti menjaga keberlangsungan generasi masa depan. Keempat, menjaga lingkungan sama dengan menjaga akal. Inilah keunggulan yang diberikan Allah SWT kepada manusia, karena dengan akal manusia diberlakukan taklif, yaitu suatu beban untuk menjalankan syari'at agama dan segala amal perbuatannya akan ditulis untuk dimintakan pertanggungjawabannya kelak. Kelima, menjaga lingkungan sama dengan menjaga harta. Menjaga lingkungan sama dengan kebutuhan pokok, yaitu menjaga harta, karena harta bagi manusia adalah bekal unutk hidup di dunia ini. Harta tidak hanya terbatas pada uang saja, akan tetapi semua benda yang menjadi milik manusia serta segala macam bentuk usaha untuk memperolehnya itu termasuk harta. Dengan demikian bumi beserta isinya merupakan harta. Sehingga menjaga lingkungan sama halnya dengan menjaga harta.

Pada dasarnya ramah lingkungan yang diajarkan oleh al-Qur'an bersumber dari fungsi manusia sebagai khalifah. Kekhalifahan menuntut adanya interaksi antara manusia dengan sesamanya dan manusia terhadap alam (Indah Muliati, 2019). Khalifah berarti wakil atau pengganti yang memegang kekuasaan. Mausia menjadi khalifah berarti manusia memperoleh mandat Tuhan untuk mewujudkan kemakmuran di muka bumi (Sukron Ma'mun, 2021).

Konsep Islam sebagai agama yang ramah terhadap lingkungan beranjak dari fungsi manusia sebagai khalifah di muka bumi, fungsi tersebut menuntut adanya interaksi harmonis antara manusia dengan sesamanya, dan manusia dengan alam sesuai dengan petunjuk-petunjuk Ilahi yang tertera dalam wahyu-Nya (Indah Muliati, 2019). Yang mana interaksi harmonis tersebut dapat berupa kewajiban manusia untuk menjaga terhadap lingkungan yang dilakukan dengan banyak cara.

Di antara konsep Islam dalam pemeliharaan lingkungan menurut Yusuf alQaradhawi (2002), adalah pertama, penanaman pohon dan penghijauan. Salah satu konsep pemeliharaan lingkungan dalam Islam adalah perhatian akan penghijauan dengan cara menanam dan bertani. Allah SWT telah menyediakan berbagai fasilitas yang melimpah untuk bercocok tanam. Hal ini diungkapkan secara lugas dalam alQur'an Surat al-An'am ayat 99: 
Rahma Hazalia dan Indah Muliati: Implementasi Konsep Islam Ramah...

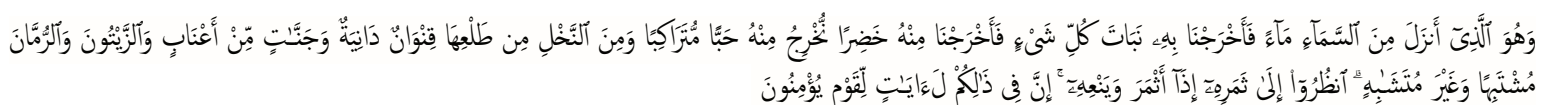

Terjemah:

"Dan Dialah yang menurunkan air hujan dari langit, lalu Kami tumbuhkan dengan air itu segala macam tumbuh-tumbuhan maka Kami keluarkan dari tumbuh-tumbuhan itu tanaman yang menghijau. Kami keluarkan dari tanaman yang menghijau itu butir yang banyak; dan dari mayang korma mengurai tangkai-tangkai yang menjulai, dan kebunkebun anggur, dan (Kami keluarkan pula) zaitun dan delima yang serupa dan yang tidak serupa. Perhatikanlah buahnya di waktu pohonnya berbuah dan (perhatikan pulalah) kematangannya. Sesungguhnya pada yang demikian itu ada tanda-tanda (kekuasaan Allah) bagi orang-orang yang beriman."

Ada dua pertimbangan mendasar mengenai penghijauan ini, pertimbangan pertama mengenai manfaat. Yakni bagaimana dari tumbuh-tumbuhan tersebut diciptakan manfaat dan nikmat yang dapat membantu memenuhi segala kebutuhan manusia. Kedua adalah keindahan. Yang mana Allah SWT sangatlah indah dan Dia sangatlah mencintai keindahan.

Kedua, menjaga kebersihan. Di antara konsep yang dianjurkan Islam dalam memelihara lingkungan adalah dengan memperhatikan masalah kebersihan. Dan pada hakikatnya pandangan Islam terhadap kebersihan merupakan sebuah prinsip yang tidak disangkal dalam agama-agama lain, karena kebersihan adalah ibadah bahkan merupakan tindakan yang diwajibkan. Dan biasanya, yang pertama kali dibahas dalam buku-buku syariat Islam adalah bab bersuci (thaharah). Pelajaran inilah yang awal pertama harus dipelajari oleh seorang muslim dan muslimah dalam dikih Islam. Itu kerena kebersihan memang merupakan kunci ibadah sehari-hari, misalnya untuk melaksanakan shalat. Diantara syarat sahnya shalat juga adalah kebersihan pakaian, tubuh, serta tempat-tempat dari kotoran.

Dalam Hadits Riwayat Muslim dari Abu Malik al-Asy'ari dalam Bab Thaharah dikatakan bahwa: "Kebersihan (kesucian) itu bagian dari Iman". Menjaga kebersihan, khususnya menjaga kebersihan lingkungan, sangat penting dalam kehidupan. Lingkungan yang bersih merupakan hak dasar setiap manusia dalam memperoleh kesehatan dalam penghidupannya. Segala sesuatu yang terjadi di lingkungan akan berpengaruh terhadap keberlangsungan kehidupan dan kesejahteraan manusia dan makhluk hidup lainnya. Dalam menjaga kebersihan lingkungan perlu kesadaran diri manusia sebagai makhluk yang memiliki pikiran (Arifin, 2012).

Ketiga, menjaga sumber kekayaan alam. Menjaga sumber kekayaan alam yang notabene merupakan nikmat Allah SWT bagi makhluk-Nya adalah kewajiban setiap manusia. Maka barangsiapa yang hendak mensyukuri nikmat tersebut, ia harus selalu menjaganya dari pencemaran, kehancuran, serta bentuk-bentuk lain yang termasuk dalam kategori peruakan di atas muka bumi.

Perusakan di atas muka bumi terkadang berbentuk fisik atau materi, seperti penghancuran tatanan lingkungan, mencemari kebersihannya, merusak keindahannya, ataupun dengan menghilangkan berbagai manfaat yang terkadung di dalamnya. Namun, di lain waktu perusakan tersebut juga dalam bentuk maknawi atau non materi. Seperti meluasnya kezhaliman, mejamurnya kebatilan, kejahatan yang semakin merajalela serta terbunuhnya hati nurani dan tersesatnya akal pikiran. Kedua bentuk perusakan tersebut tentu sangat dibenci oleh Allah SWT. 
Keempat, menjaga kesehatan manusia. Jika kita diwajibkan untuk menjaga sumber daya alam, baik berupa kekayaan hewani, pertanian, maupun air, maka yang harus lebih diperhatikan lagi adalah bagaimana menjaga sumber daya manusia sebagai khalifah Allah di muka bumi ini.

Sebab tak dapat dipungkiri bahwa sumber daya yang paling berharga serta kekayaan yang paling mahal harganya adalah kesehatan manusia. Inilah sebenarnya tujuan utama dai penjagaan terhadap sumber daya apa pun. Karena memang Allah SWT menyediakan semua itu untuk umat manusia. Sekaligus menjadikan manusia sebagai pelaksana dan mediator dalam menjaga sumber daya alam.

\section{Metode}

Metode yang dipakai dalam penelitian ini adalah penelitian kualitatif dengan menggunakan metode analisis deskriptif (Murniyetti el al., 2016; Kasmar et al., 2019; Damri et al., 2020; Maputra et al., 2020). Jenis penelitian yang digunakan adalah penelitian lapangan (field reserach). Pada penelitian ini peneliti langsung turun ke lapangan untuk menganalisa serta menyajikan sebuah fakta tentang implementasi konsep Islam ramah lingkungan di MTsN 2 Padang Pariaman.

Untuk mendapatkan data yang kongkrit maka peneliti menggunakan teknik pengumpulan data dengan cara observasi, wawancara dan dokumentasi. Informan yang peneliti wawancarai terdiri dari Kepala Sekolah, Staf Tata Usaha, dua guru serta 3 murid MTsN 2 Padang Pariaman. Setelah data dikumpulkan, data dianalisa dengan cara pengumpulan data, reduksi data, penyajian data dan penyimpulan data.

Selanjutnya keabsahan data penelitian ini ditentukan dengan menggunakan teknik triangulasi. Triangulasi dalam pengujian kredibilitas diartikan sebagai pengecekan data dari berbagai sumber dengan berbagai cara dan berbagai waktu (Etta Mamang Sangadji dan Sopiah: 200). Teknik triangulasi data yang digunakan adalah triangulasi sumber, yaitu menguji kredibilitas sebuah data dengan cara melakukan pengecekkan berbagai sumber dalam memperoleh sebuah informasi, yaitu tidak hanya diambil dari satu sumber saja, namun terdapat beberapa sumber informasi yang mendukung penelitian ini, diantaranya kepala sekolah, guru, dan juga siswa MTsN 2 Padang Pariaman.

\section{Hasil dan Pembahasan}

Berdasarkan hasil wawancara yang dilakukan kepada tujuh orang informan, hasil analisis secara nyata mendapati bahwa terdapat empat tema penting terkait implementasi Konsep Islam Ramah Lingkungan di MTsN 2 Padang Pariaman. Empat tema tersebut dapat terlihat pada gambar 1 , berikut. 


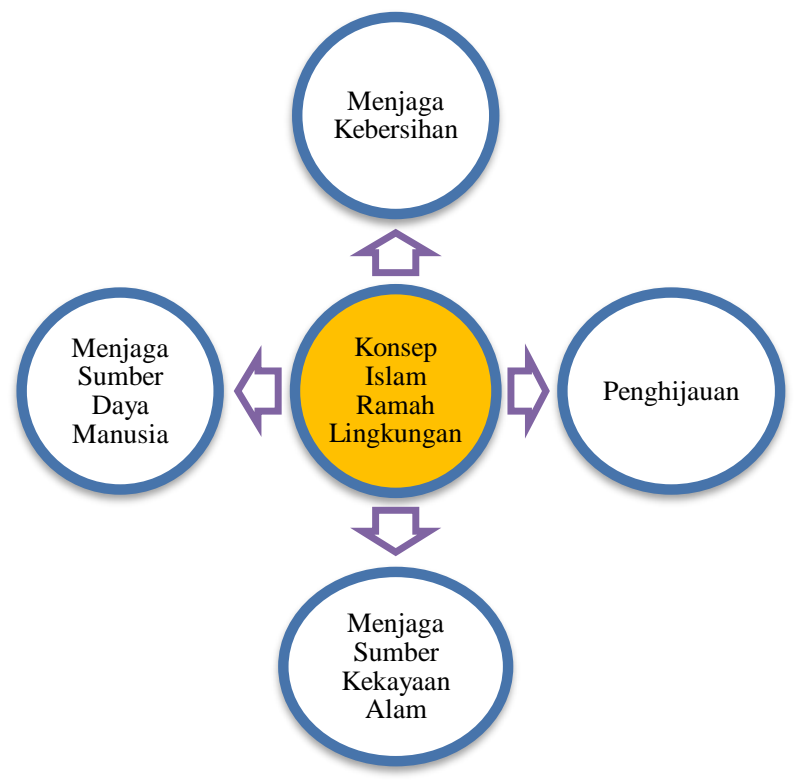

Gambar 1. Deskripsi Konsep Islam Ramah Lingkungan di MTsN 2 Padang Pariaman

Berdasarkan gambar 1, dapat penulis jelaskan bahwa setelah diadakan wawancara mendalam dengan informan maka terdapat empat tema implementasi konsep islam ramah lingkungan di MTsN 2 Padang Pariaman, yaitu i) menjaga kebersinhan, ii) penghijauan, iii) menjaga sumber kekayaan alam, iv) menjaga sumber daya manusia.

Agar lebih menarik, berikut ini akan peneliti deskripsikan kutipan hasil wawancara dengan informan berdasarkan empat tema sebagaimana telah dijelaskan di atas. Adapun deskripsi wawancara yang akan penulis tampilkan adalah kutipan pernyataan singkat dari informan ketika wawancara dilakukan. Kutipan-kutipan wawancara tersebut walaupun disampaikan informan dalam redaksi bahasa yang sedikit berbedabeda, namun sebenarnya mempunyai tujuan dan maksud yang kurang lebih sama.

Tema pertama dalam pemeliharaan lingkungan yang diterapkan di MTsN 2 Padang Pariaman yakni menjaga kebersihan. Baik itu kebersihan diri sendiri ataupun kebersihan lingkungan. Ini dapat dilakukan dengan cara membersihkan atau menghilangkan sesuatu yang berbahaya seperti tidak ada tanaman berduri yang ditanam di sekolah ini. Serta menjaga kebersihan lingkungan dengan cara tidak membuang sampah sembarangan. Ataupun menjaga kebersihan tempat-tempat yang ada di sekolah, seperti tempat ibadah, ruang kelas, ruang guru serta toilet. Namun sangat disayangkan, dalam hal ini masih kurang diterapkan di sekolah tersebut. Berikut petikan wawancara mengenai tema pertama:

Tabel 1. Petikan Wawancara Tema Pertama

\begin{tabular}{lcl}
\hline Tema & Informan & Petikan Wawancara \\
\hline Menjaga & 6 & Kita dilarang membuang sampah sembarangan. Kalau \\
Kebersihan & ketahuan buang sampah sembarangan akan kena \\
& hukum, seperti kena denda atau disuruh membersihkan \\
& halaman mencabut rumput \\
\hline
\end{tabular}




\begin{tabular}{cl}
\hline 2 & $\begin{array}{l}\text { Madrasah sendiri merupakan sekolah yang } \\
\text { berlandaskan kepada Islam, jadi dengan berlandaskan } \\
\text { pada Islam atau prinsip Islam yaitu harus bersih }\end{array}$ \\
\hline 7 & $\begin{array}{l}\text { Kalau membuang sampah sembarangan, kita akan kena } \\
\text { hukum, bayar denda seribu atau dua ribu tergantung } \\
\text { banyak sampah yang dibuang, atau kita disuruh } \\
\text { mencabut rumput di halaman atau di taman kelas }\end{array}$ \\
& $\begin{array}{l}\text { Konsep yang sangat penting, yang utama diterapkan } \\
\text { dalam ramah lingkungan di madrasah ini tentu menjaga } \\
\text { kebersihan }\end{array}$ \\
\hline
\end{tabular}

Tema kedua, perhatian akan penghijauan dengan cara menanam. Ada dua pertimbangan mendasar dari upaya penghijauan ini. Pertimbangan pertama adalah pertimbangan manfaat. Yang mana dari tumbuh-tumbuhan itu diciptakan manfaat dan nikmat yang dapat membantu memenuhi kebutuhan manusia. Dan pertimbangan yang kedua adalah keindahan. Dari tumbuh-tumbuhan yang ditanam dapat membuat keindahan yang berarti menyejukkan jiwa, mata dan hati ketika memandangnya (Yusuf al-Qaradhawi, 2002)

Konsep Islam ramah lingkungan yang ditanamkan di MTsN 2 Padang Pariaman adalah penghijauan atau perhatian akan lingkungan yang asri. Maksudnya yaitu perhatian terhadap lingkungan dengan cara melakukan penghijauan atau penanaman tanaman agar lingkungan tetap asri. Ini sesuai dengan penjelasannya sebelumnya, bahwa ada dua pertimbangan mendasar dalam kegiatan penghijauan ini. Yakni pertimbangan manfaat dan pertimbangan keindahan. Dengan penghijauan, tumbuhtumbuhan yang ditanam tentu memiliki manfaat dan nikmat yang dapat membantu memenuhi segala kebutuhan manusia. Dengan adanya tanaman obat-obatan seperti daun betadine yang bermanfaat dan membantu dalam proses penyembuhan luka. Dan juga dengan adanya tumbuh-tumbuhan maka lingkungan akan menjadi indah. Yang mana Allah SWT sangatlah indah dan Dia sangatlah menyukai keindahan. Berikut petikan wawancara mengenai tema kedua:

Tabel 2. Petikan Wawancara Tema Kedua

\begin{tabular}{lcl}
\hline Tema & Informan & Petikan Wawancara \\
\hline Penghijuan & 1 & $\begin{array}{l}\text {....kita selalu menanamkan segala sesuatu bagi anak- } \\
\text { anak itu konsep bagaimana ia bisa mengerti dan } \\
\text { memberi perhatian terhadap lingkungan yang asri }\end{array}$ \\
\cline { 2 - 4 } & 2 & $\begin{array}{l}\text { Karena adiwiyata itu kan sama dengan go green yang } \\
\text { mana lingkungan sekolah itu agar terlihat bersih, indah, } \\
\text { rindang, asri dan adem }\end{array}$ \\
\cline { 2 - 4 } & $\begin{array}{l}\text { Dengan cara menanam pohon atau bunga agar } \\
\text { lingkungan di madrasah kita ini tetap terlihat asri dan } \\
\text { adem }\end{array}$ \\
\hline
\end{tabular}

Tema ketiga, menjaga sumber kekayaan alam yang notabene merupakan nikmat Allah SWT bagi makhluk-Nya, adalah kewajiban setiap manusia. Maka barangsiapa yang hendak mensyukuri nikmat tersebut, ia harus selalu menjaganya dari pencemaran, kehancuran, serta bentuk-bentuk lain yang termasuk dalam kategori perusakan di atas bumi (Yusuf al-Qaradhawi, 2002). 
Rahma Hazalia dan Indah Muliati: Implementasi Konsep Islam Ramah...

Untuk itu konsep Islam dalam pemeliharaan lingkungan yang selanjutnya diterapkan di MTsN 2 Padang Pariaman adalah menjaga sumber kekayaan alam. Yang mana siswa diminta untuk dapat memberi perhatian baik kepada tumbuh-tumbuhan atau kepada hewan sebagaimana perhatian kepada diri sendiri. Ini sesuai dengan yang diajarkan Islam dalam pemeliharaan sumber kekayaan alam. Seperti menjaga hewan dengan cara memberinya makan, merawatnya, membersihkan tempatnya dan lainnya. Serta perhatian akan tumbuh-tumbuhan dengan cara menyiramnya secara rutin, memberinya pupuk, dan lainnya. Tidak hanya konsep perhatian akan kekayaan nabati atau hewan saja, tetapi perhatian akan kekayaan air juga sangat dituntut di lingkungan sekolah ini. Yang mana siswa tidak dibenarkan memakai air secara boros, dan sebagai usaha dalam menghemat air maka dibuatkan stiker peringatannya disetiap keran. Berikut petikan wawancara tema ketiga:

Tabel 3. Petikan Wawancara Tema Ketiga

\begin{tabular}{|c|c|c|}
\hline Tema & Informan & Petikan Wawancara \\
\hline \multirow{4}{*}{$\begin{array}{l}\text { Menjaga } \\
\text { Kekayaan } \\
\text { Alam }\end{array}$} & & Kita mengajarkan kepada anak-anak kita, shaleh dan \\
\hline & 1 & $\begin{array}{l}\text { shalehah bahwasannya semua yang ada ini sama dengan } \\
\text { kita, sama-sama makhluk Allah SWT..., ,....Bagaimana } \\
\text { kita memperdayakan, memperlakukan tumbuh- } \\
\text { tumbuhan yang ada itu seperti kita memperdayakan diri } \\
\text { kita sendir }\end{array}$ \\
\hline & 3 & $\begin{array}{l}\text { Di madrasah kita ini, anak tidak dibenarkan dalam } \\
\text { memakai air terlalu boros, kemudian dibuatkan SOP } \\
\text { nya... }\end{array}$ \\
\hline & 4 & $\begin{array}{l}\text { Untuk menyiram bunga, kita sesuai dengan piket kelas. } \\
\text { Siapa yang piket hari itu, jadi dia yang menyiram bunga } \\
\text { di taman kelas setiap pagi dan pulang sekolah }\end{array}$ \\
\hline
\end{tabular}

Tema keempat, Jika kita diwajibkan untuk menjaga sumber kekayaan alam berupa air, hewan atau tumbuh-tumbuhan, yang harus lebih diperhatikan adalah bagaimana menjaga sumber daya manusia debagai khalifah Allah SWT di muka bumi. Karena Allah SWT menyediakan itu semua untuk umat manusia dan juga manusia itulah yang menjadi pelaksana dan mediator dalam menjaga sumber daya alam. Sebagaimana yang disebutkan dalam hadits riwayat Bukhari, bahwa: "Sesungguhnya tubuhmu memiliki hakyang harus kamu penuhi."

Hak-hak tersebut diantaranya adalah harus membersihkan tubuh jika kotor, memberikan konsumsi jika lapar, mengistirahatkannya jika lelah, melindunginya dari panas dan dingin, mengobatinya apabila terserang penyakit, serta hal-hal lain yang diketahui manusia dari instuisi maupun pengalaman (Yusufal-Qaradhawi, 2002).

Untuk itu konsep menjaga kesehatan manusia yang diterapkan di MTsN 2 Padang Pariaman baik itu dari memperhatikan masalah makanannya dan juga kesehatan lingkungan sekitarnya, dilakukan dengan cara sekolah menghimbau kepada para siswa untuk membawa bekal dari rumah dan melarang jajan sembarangan di luar. Serta tidak adanya tanaman yang berduri yang dikhawatirkan akan dapat mencederai siswa. Dan juga dengan adanya UKS akan sangat membantu jika ada siswa yang sakit ataupun karena lainnya. Demikianlah sekolah berusaha untuk dapat menerapkan konsep Islam ramah lingkungan dalam hal menjaga kesehatan manusia. 
Tabel 4. Petikan Wawancara Tema Keempat

\begin{tabular}{|c|c|c|}
\hline Tema & Informan & Petikan Wawancara \\
\hline \multirow[t]{4}{*}{$\begin{array}{l}\text { Peluang } \\
\text { pekerjaan } \\
\text { setelah } \\
\text { lulus }\end{array}$} & 2 & $\begin{array}{l}\text {,... sebagai contoh anak-anak kita suruh untuk bawa bekal } \\
\text { dari rumah, dilarang jajan sembarangan di luar, dan juga } \\
\text { disini kita tidak ada tanaman atau bunga-bunga yang } \\
\text { berduri, yang tajam,... }\end{array}$ \\
\hline & 3 & $\begin{array}{l}\text {...kita melarang siswa jajan sembarangan dan menyuruh } \\
\text { siswa untuk membawa bekal rumah masing-masing,... }\end{array}$ \\
\hline & 4 & $\begin{array}{l}\text {. Jadi untuk mengantisipasinya pertama itu dariair minum } \\
\text { anak dulu yaitu disuruh bawa minum dari rumah, } \\
\text { kemudian disuruh bawa makanan dari rumah. }\end{array}$ \\
\hline & 7 & $\begin{array}{l}\text { Kita disuruh bawah nasi dari rumah. Kalau di kelas Ica itu } \\
\text { diwajibkan, jadi bagi yang tidak membawa nasi akan kena } \\
\text { denda. Pas jam istirahat, nanti kita akan makan bersama } \\
\text { di kelas }\end{array}$ \\
\hline
\end{tabular}

Dalam melaksanakan konsep-konsep di atas, MTsN 2 Padang Pariaman memberlakukan beberapa tahap pengimplementasian yaitu perencanaan, pelaksanaan, dan evaluasi.

Untuk perencanaan dari konsep Islam ramah lingkungan di MTsN 2 Padang ini tidak lepas dari visi misi sekolah serta program sekolah yang ramah lingkungan. Yang mana program-program tersebut tentu ada perencanaan sebelumnya. Yaitu awal ketika mengajukan sekolah menjadi calon sekolah adiwiyata tentu ada perencanaan program yang akan dibuat yang sesuai dengan ketentuan adiwiyata. Serta sekolah yang merupakan madrasah atau sekolah Islam, tentu sekolah ini harus menjalankan konsepkonsep ramah lingkungan menurut Islam dengan baik.

Pelaksanaan konsep ramah lingkungan di MTsN 2 Padang Pariaman sudah mulai diterapkan dengan baik. Seperti dalam hal menjaga kebersihan sudah mulai diterapkan dengan baik di sekolah ini. Yakni dengan cara berwudhu, dilarang membuang sampah sembarangan serta dapat mengolah sampah tadi menjadi kompos. Sedangkan pelaksanaan dari konsep penghijauan, sekolah ini sudah mulai menerapkannya dengan baik, ini terlihat dari lingkungan sekolah yang asri, dengan adanya pohon pelindung, tanam-tanaman baik itu tanaman hias atau pun tanaman obat-obatan. Dan tepat di depan ruang guru terdapat taman yang berisikan tanam-tanaman obat berupa lidah buaya, daun betadine, daun sirih, jahe, dan lainnya. Dan untuk konsep menjaga sumber kekayaan alam, sekolah ini masih kurang menerapkannya. Ini terlihat dari kolam ikan yang tidak terurus, yang mana terdapat banyak daun-daun di dalam kolam, sehingga air kolam menjadi keruh dan kondisi kolam kurang bersih. Serta dalam konsep menjaga kesehatan manusia, sekolah sudah menerapkannya dengan baik. Seperti dengan diwajibkannya siswa untuk membawa bekal dari rumah, serta adanya kerjasama antara sekolah dengan puskesmas untuk memberikan pengarahan kepada para pedagang kantin tentang makanan yang sehat dan juga kontrol rutin dari puskesmas, berupa pemberian tablet tambah darah, cek kesehatan dan lainnya. 
Rahma Hazalia dan Indah Muliati: Implementasi Konsep Islam Ramah...

Terakhir, kegiatan evaluasi dilakukan. Evaluasi adalah suatu proses merencanakan, memperoleh dan menyediakan informasi yang sangat diperlukan untuk membuat alternatif-alternatif keputusan (Purwanto, 2006). Sesuai dengan pengertian tersebut, evaluasi atau penilaian yang sengaja di rencanakan untuk mendapatkan informasi atau data yang kemudian dicoba untuk membuat suatu keputusan.

Adapun evaluasi dalam penerapan konsep Islam ramah lingkungan di MTsN 2 Padang Pariaman yakni dengan adanya program 9K. Yang mana program ini menilai kebersihan kelas, kerapian, serta taman kelas dan juga tempat sampah masing-masing kelas. Dengan program ini siswa akan lebih termotivasi untuk menerapkan ramah lingkungan di sekolah sehingga dapat menciptakan lingkungan sekolah bersih dan nyaman.

Dalam proses pengimplementasian konsep islam ramah lingkungan di MTsN 2 Padang Pariaman, peneliti menemukan faktor-faktor yang mendukung dan menghambat jalannya proses pengimplementasian. Faktor-faktor ini mempengaruhi secara langsung tingkat pengimplementasian konsep islam ramah lingkungan yang dilakukan di MTsN 2 Padang Pariaman.

Untuk itu, faktor penghambat dalam implementasi konsep Islam ramah lingkungan di MTsN 2 Padang Pariaman ini adalah:

1) Rasa malas dari siswa

Masih ada beberapa siswa yang masih malas dalam mengerjakan piket kelas. Untuk itu ada beberapa wali kelas yang sampai mengawasi siswanya dalam piket kelas agar tidak ada lagi siswa yang tidak mengerjakan piket.

2) Kurangnya kesadaran siswa untuk menjaga lingkungan

Beberapa siswa masih ada yang membuang sampah sembarangan. Padahal sekolah sudah membuat larangan membuang sampah sembarangan dan memberikan sanksi kepada siswa yang melanggar.

3) Lingkungan siswa di luar sekolah

Lingkungan siswa yang berbeda-beda di luar sekolah menjadi salah satu faktor penghambatnya. Karena lingkungan memiliki pengaruh yang besar.

4) Perbedaan karakter dari masing-masing siswa

Setiap siswa pasti memiliki karakter yang berbeda-beda. Ada beberapa siswa yang mau dinasehati ataupun tanpa disuruh ia sudah melakukannya duluan. Ada juga siswa yang sudah dikenakan denda atau sanksi lainnya, akan tetapi tetap saja masih melanggar.

5) Pengaruh gadget

Gadget sangat memberikan pengaruh besar pada diri siswa. Pengaruh yang diberikan tergantung dari cara siswa dalam menggunakannya.

Adapun faktor pendukung dalam implementasi konsep Islam ramah lingkungan di MTsN 2 Padang Pariaman adalah:

1) Pengawasan dari guru

Dengan pengawasan dari guru, seperti pengawasan dalam mengerjakan piket kelas, para siswa tentu akan melakukannya karena mereka diawasi dan tidak bisa untuk mengelak.

2) Adanya denda atau hukuman atas pelanggaran yang dilakukan

Dengan adanya denda atau sanksi berupa hukuman, sekolah berharap agar siswa tidak ada lagi yang melanggar aturan yang sudah dibuat. 
3) Dukungan dari orangtua siswa

Dukungan dari orangtua tentu sangat dibutuhkan. Disini dapat dicontohkan dengan siswa membawa bekal ke sekolah, yang mana bekal tersebut sudah disiapkan oleh orangtua sebelumnya.

4) Lingkungan sekolah yang ramah terhadap lingkungan

Lingkungan yang sekolah dibuat seramah mungkin menjadi faktor pendukung dalam implementasi konsep ramah lingkungan ini.

5) Contoh positif dari guru-guru di sekolah

Guru harus dapat memberikan contoh yang baik kepada para siswanya. Baik dalam hal berpakaian, bertutur kata, kebiasaan dan lainnya.

\section{Simpulan}

Konsep Islam ramah lingkungan yang diterapkan di sekolah ini ada empat konsep yaitu menjaga kebersihan, penghijauan, menjaga sumber kekayaan alam, serta menjaga kesehatan manusia. Konsep Islam ramah lingkungan ini tidak lepas dari visi misi sekolah serta program sekolah yang ramah ligkungan. Yang mana rencana awal dari program tersebut ketika mengajukan sekolah menjadi calon sekolah adiwiyata. Maka dibuatlah program-program ramah lingkungan yang sesuai dengan ketentuan adiwiyata. Bentuk penerapannya seperti dilarang membuang sampah sembarangan, memilah sampah sesuai dengan jenisnya, mengolah sampah menjadi kompos, menanam berbagai tanaman baik itu tanaman hias atau tanaman obat, mewajibkan siswa membawa bekal dari rumah, adanya kerjasama sekolah dengan puskesmas dalam memberikan pengarahan kepada para pedagang kantin tentang makanan yang sehat, serta adanya kontrol rutin dari puskesmas kepada para siswa berupa pemeriksaan kesehatan ataupun pemberian tablet tambah darah. Dan untuk evaluasi dari konsep yang sudah diterapkan tadi, MTsN 2 Padang Pariaman mengadakan program 9K. Faktor penghambat dan pendukung dalam implementasi konsep Islam ramah lingkungan di MTsN 2 Padang Pariaman yaitu: Pertama, rasa malas dari siswa. Kedua, kurangnya kesadaran siswa untuk menjaga lingkungan. Ketiga, lingkungan siswa di luar sekolah. Keempat, perbedaan karakter dari masing-masing siswa. Kelima, pengaruh gadget. Sedangkan faktor pendukung dalam implementasi konsep Islam ramah lingkungan di MTsN 2 Padang Pariaman adalah: Pertama, pengawasan dari guru. Kedua, adanya denda atau hukuman atas pelanggaran yang dilakukan. Ketiga, dukungan dari orangtua siswa. Keempat, lingkungan sekolah yang ramah terhadap lingkungan. Kelima, contoh positif dari guru-guru di sekolah.

\section{Referensi}

Afifah, E. N. (2019). Fiqih Ramah Lingkungan Perspektif Yusuf Qardawi (Studi Kasus Pertambangan Pasir Batu di Desa Kecamatan Jenangan Kabupaten Ponorogo). Institut Agama Islam Negeri Ponorogo.

Alim, M. (2011). Pendidikan Agama Islam Upaya Pembentukan Pemikiran dan Kepribadian Muslim. Bandung: PT Remaja Rodakarya.

Al-Qaradhawi, Y. (2002). Islam Agama Ramah Lingkungan, terj. Jakarta: Pustaka Kautsar.

Arikunto, S. (1992). Prosedur Penelitian: Suatu Pendekatan Praktik. Rineka cipta.

Damri, D., Engkizar, E., Syafril, S., Asril, Z., Munawir, K., Rahawarin, Y., ... Tulum, L.T., \& Amnda, V. (2020). Factors and Solutions of Students'bullying Behavior. Jurnal Kepemimpinan dan Pengurusan Sekolah, 5(2), 115-126. 
Rahma Hazalia dan Indah Muliati: Implementasi Konsep Islam Ramah...

Departemen Agama RI. (2013). Al-Qur'an dan Terjemahannya. Jakarta: Yayasan Penerjemah dan Penerbit Al-Qur'an.

Departemen Pendidikan dan Kebudayaan. (2007). Kamus Besar Bahasa Indonesia. Jakarta: Balai Pustaka.

Engkizar, E., Muliati, I., Rahman, R., \& Alfurqan, A. (2018). The Importance of Integrating ICT into Islamic Study Teaching and Learning Process. Khalifa: Journal of Islamic Education, 1(2), 148-168.

Engkizar, E., Munawir, K., Kaputra, S., Arifin, Z., Syafril, S., Anwar, F., \& Mutathahirin, M. (2021). Building of Family-based Islamic Character for Children in Tablighi Jamaat Community. Ta'dib, 24(2), 116-126.

Hardiana, D. (2018). Perilaku Masyarakat Dalam menjaga Kebersihan lingkungan Lingkungan Pantai Kecamatan Sasak Ranah Pasisie Kabupaten Pasaman Barat. Jurnal Buana, 2 (2), 495-506.

Hipzon. (2018). Pelestarian Lingkungan Dalam Pandangan Islam (Studi di Desa Pasaduka Kecamatan Ngaras Kabupaten Pesisir Barat). Universitas Islam Negeri Raden Intan Lampung.

Ibrahim, R. dkk. (2017). Konsep Ramah Lingkungan Dalam Perspektif Al-Qur'an, Hadis, Dan Kitab Kuning Di Pesantren. Madania, 21 (2), 209-220.

Kaputra, S., Engkizar, E., Akyuni, Q., Rahawarin, Y., \& Safarudin, R. (2021). Dampak Pendidikan Orang Tua Terhadap Kebiasaan Religius Anak dalam Keluarga Jama'ah Tabligh. Al-Tadzkiyyah: Jurnal Pendidikan Islam, 12(2), 249-268.

Kasmar, I. F., Amnda, V., Mutathahirin, M., Maulida, A., Sari, W. W., Putra, S., ... \& Engkizar, E. (2019). The Concepts of Mudarris, Mu'allim, Murabbi, Mursyid, Muaddib in Islamic Education. Khalifa: Journal of Islamic Education, 3(2), 107125.

Ma'mun, S. (2021). Tanggung Jawab Manusia Terhadap Alam. Binus University.

Maputra, Y., Syafril, S., Wekke, I. S., Sabiruddin, J., Anggreiny, N., Sarry, S. M, Engkizar, E. (2020). Building Family's Social Resilience through Batobo Culture: A community environment proposal. E\&ES, 469(1), 012062.

Marhijanto, B. Kamus Lengkap Bahasa Indonesia Masa Kini. Surabaya: Terbit Terang.

Muliati, I. (2019). Ramah Lingkungan Dalam Islam. Reseachgate.net.

Mulyadi. (2018). Konsep Islam Dalam al-Qur'an Perspektif Tekstual Dan Kontekstual. Islamuna, 5(1).

Murniyetti, M., \& Engkizar, E. (2022). The Practice Of Pagang Gadai Of High Heritage Assets In Kanagarian Ganggo Mudiak In The Perspective Of Islamic Law. Ijtimaiyya: Jurnal Pengembangan Masyarakat Islam, 14(2), 187-204.

Murniyetti, M., Engkizar, E., \& Anwar, F. (2016). Pola pelaksanaan pendidikan karakter terhadap siswa sekolah dasar. Jurnal Pendidikan Karakter, 6(2).

Ramly, N. (2007). Islam Ramah Lingkungan (Konsep dan Strategi Islam dalam Pengelolaan, Pemeliharaan dan Penyelamatan Lingkungan). Jakarta Selatan: Penerbit Grafindo Khazanah Ilmu.

Saharuddin. (2014). Islam Dan Ramah Lingkungan (Studi Atas Teologi Lingkungan Hidup). Universitas Islam Negeri Alauddin Makassar.

Sangadji, E. M \& Sopiah. (2010). Metodologi Penelitian-Pendekatan Praktis dalam Penelitian. Yogyakarta: ANDI.

Syaltout, M. (1996). Al-Islam Aqidah Wa Syari'ah. Mesir: Dar al-Qolam.

Widyadipraja, C. (2020). Mencintai Lingkungan Hidup Menurut Konsep Islam. Binus University. 